\title{
Farmer preferences and legume intensification for low nutrient environments
}

\author{
S.S. Snapp ${ }^{1,3} \&$ S.N. Silim ${ }^{2}$ \\ ${ }^{1}$ Department of Horticulture, Michigan State University, East Lansing, MI 48824-1325, formerly ICRISAT, \\ P.O. Box 1096, Lilongwe, Malawi. ${ }^{2}$ Principal Scientist Agronomy, ICRISAT P.O. Box 39063, Nairobi, Kenya. \\ ${ }^{3}$ Corresponding author*
}

Received 10 May 2000. Accepted in revised form 14 December 2000

\begin{abstract}
Improved varieties of legumes adapted to nutrient deficiency have the potential to improve food security for the poorest farmers. Tolerant varieties could be an inexpensive and biologically smart technology that improves soils while minimizing fertilizer costs. Yet other technologies that improve productivity and appear to be biologically sound have been rejected by farmers. To translate benefits to smallholder farmers, research on low-nutrient tolerant genes and crop improvement must keep farmer preferences and belief systems in the forefront. We review farmer participatory research on legume-intensification and soil fertility management options for smallholder farmers in Africa, including recent results from our work in Malawi and Kenya. We suggest that indeterminate, longduration legumes are the best bet for producing high quality residues, compared to short-duration and determinate genotypes. This may be due to a long period of time to biologically fix nitrogen, acquire nutrients, photosynthesize and grain fill. Also, the indeterminate nature of long-duration varieties facilitates recovery from intermittent stresses such as drought or pest pressure. However, indeterminate growth habit is also associated with late maturity, moderate yield potential and high labour demand. These traits are not necessarily compatible with smallholder criteria for acceptable varieties. Malawi women farmers, for example, prioritized early maturity and low-labour requirement, as well as yield potential. To address complex farmer requirements, we suggest the purposeful combination of species with different growth habits; e.g. deep-rooted indeterminate long-duration pigeonpea interplanted with short-duration soyabean and groudnut varieties. On-farm trials in Malawi indicate that calorie production can be increased by $30 \%$ through pigeonpea-intensified systems. Farmers consistently indicate strong interest in these systems. In Kenya, a 55\% yield increase was observed for a doubled-up pigeonpea system (a double row of pigeonpea intercropped with three maize rows) compared to traditional, low density intercrops. However, the need for improved pigeonpea varieties with high intercrop suitability, including reduced early branching, was highlighted by a farmer preference study in the same area. These examples illustrate the potential for participatory research methodologies to drive biophysical research in farmer-acceptable directions.
\end{abstract}

\section{Introduction}

Varieties adapted to low fertility soils open up new possibilities for the most food insecure, resource-poor farmers. Smallholder farmers rarely have sufficient cash to invest in fertilizers, or labour to invest in making compost. In contrast to fertilizers, it is possible for even the poorest farmers to try out new varieties. The technology has the potential to reach more farm-

\footnotetext{
* FAX No: 517-432-2242. E-mail: snapp@msu.edu
}

ers because seeds can move from farmer to farmer, seeds are relatively low cost, and farmers can produce their own seeds. The limited investment requirement with new varieties improves adoption potential, but it is only one aspect of farmer acceptance. Understanding client perceptions and priorities is also crucial to facilitating farmer adoption (Chambers and Ghildyal, 1985; Sperling et al., 1993).

To investigate farmer perceptions, new participatory research approaches help elicit farmer selec- 
tion criteria and strategies (Kitch et al., 1998). Importantly, a participatory action research agenda can provide information to researchers about farmers beliefs while simultaneously facilitating farmer experimentation (Defoer et al., 1998). Socio-economic surveys are also a key tool to understanding farmer practice and belief (Ahmed et al., 1998). Farmers are not a uniform group by any means. We discuss examples of how gender can influence farmer preferences, such as demand by women farmers for varieties and systems with lower labour requirements (Kolli and Bantilan, 1997). Women farmers are also often concerned with, and may have a high degree of indigenous knowledge concerning, secondary uses of crops and quality factors, such as taste of leaves in bean and cowpea (Ferguson, 1994; Kitch et al., 1998).

In this paper, we focus on recent research evaluating legume-based technologies appropriate to smallholder farmers in Southern and Eastern Africa. Farmer preferences include complex criteria, such as: Adaptation to local conditions, yield security, cash returns, grain quality traits, tolerance to abiotic and biotic stresses, market context, production of secondary benefits (e.g. fuelwood, pesticides, soil fertility) and low labour requirements (Fischler et al., 1996; Sperling et al., 1993). Farmer criteria often incorporate a combination of traits, which may be negatively correlated or even mutually exclusive (CARE, 1998). One approach to this conundrum is for researchers to develop a wide range of varieties, and integrative systems that include both early and late maturity genotypes. Intercrop systems have been shown to reduce food security risk through compensation (Willey et al., 1997). We contend that intercrop systems can be designed to not only buffer against food shortages, but simultaneously to conserve land through longer foliage cover. Through case studies, we suggest that combining varieties with a range of growth types is required to address multiple objectives such as enhanced yield potential, reduced labour demand and soil enhancing properties.

Incorporating farmer involvement in a systematic fashion is a key factor to addressing the complex criteria held by smallholder farmers. Testing and farmer evaluation of varieties may be best done in the context of a multiple species cropping systems. Examples from the literature, and are own experiences, suggest that evaluation of variety performance in sole crops is inadequate: intercrop and rotation systems must be considered from inception (Ferguson, 1994; ICRISAT, 1998; Willey et al., 1997). This may be particularly true for varieties targeted at low soil fertility and en- vironmentally stressed farming systems (Fischler et al., 1996). It is a challenging job to develop varieties that meet multiple farmer criteria, and tolerate low nutrient soils. Farmers require firsthand knowledge to assess intercropping and legume-intensification technologies, which often require substantial labour and skilled management. Furthermore, there may be collateral benefits, such as weed suppression, that farmers need to observe for themselves (Kanyama-Phiri et al., 2000; Snapp et al., 1998B).

\section{Farmer perceptions of returns and constraints}

Farmer preferences are determined by their perceptions of the returns possible, and the constraints they face. Researchers usually monitor returns by measuring crop yields per land area. However, farmers assess a range of complex traits, and their perceptions of returns may be different than researchers. Farmer perceptions and beliefs need to be assessed as well as monitoring performance and economic returns (Heong and Escalada, 1999). This particularly holds for crops grown to provide variety in diet and to provide secondary benefits such as building material, fuelwood, fodder, pesticide and medicinal. Cowpea is an example of a crop generally grown to meet multiple objectives, yet plant breeding efforts initially focused almost exclusively on grain yield and improving the harvest index (Kitch et al., 1998). This reduced the amount of forage produced, which conflicted with a key farmer objective, and it ignored the use of cowpea leaves for home consumption.

In 1998, a semi-formal survey was conducted in Malawi by one of the authors (S. Snapp) to elicit criteria for evaluating legume-intensified systems from 114 farmers through open-ended questions on negative and positive traits. Surveys were reviewed, and 99 farmer responses were complete enough to use for analysis. Results were summarized by categories for the most common responses, as a percentage of responses for negative and positive traits (after Kitch et al., 1998). The range of criteria used to evaluate legume 'best bets' are presented, for male farmers (Table 1) and for female farmers (Table 2). Overall, $50 \%$ of positive and $70 \%$ of negative traits were concerned with returns, where returns were yields and secondary products that enhanced food security, market sales or multiple minor uses. As the technologies were tested with farmers who had volunteered to test soil fertility management practices, it was expected 
Table 1. Criteria used by male farmers in evaluating performance of soil fertility technologies in multilocational trials in 1997. The criteria were elicited by asking farmers to list positive and negative traits associated with each technology they had evaluated in on-farm trials

\begin{tabular}{|c|c|c|c|c|}
\hline \multirow[t]{3}{*}{ Positive traits } & \multicolumn{4}{|c|}{ Technology ${ }^{a}$} \\
\hline & Mz control & Maize/PP & $\mathrm{Leg} / \mathrm{PP}$ & Maize/Tv \\
\hline & \multicolumn{4}{|c|}{ Percentage of total responses ${ }^{b}$} \\
\hline Less labour & 1.2 & & & \\
\hline Labour less/2crops & & 3.1 & 3.8 & \\
\hline Less weeds & & 3.1 & 5.4 & 2.3 \\
\hline Increased land efficiency & & 2.7 & 3.4 & \\
\hline \multicolumn{5}{|l|}{2 crops/area } \\
\hline Few pests & & 1.1 & 0.8 & \\
\hline Good emergence & 0.8 & & & \\
\hline Water conservation & & & & 4.5 \\
\hline Early Harvest & 2.6 & 1.9 & 3.1 & \\
\hline Good yields/food security & & 9.6 & 10 & 4.2 \\
\hline Fuelwood & & 2.7 & 0.4 & 2.3 \\
\hline Increased soil fertility & & 7.3 & 6.9 & 5 \\
\hline Pesticide & & & & 0.8 \\
\hline Increased cash sales & & 5 & 6.1 & \\
\hline$S U M$ & 4.6 & 36.5 & 39.9 & 19.1 \\
\hline \multicolumn{5}{|l|}{ Negative traits } \\
\hline Increased labour & 0.6 & 0.6 & 1.7 & 5.1 \\
\hline Increased weeds & 1.7 & & & \\
\hline Limited seed access & & 5.1 & 6.2 & 4.5 \\
\hline Expensive fertilizer & 2.3 & & & \\
\hline Low yields & 15.3 & 1.7 & 2.2 & 7.9 \\
\hline Slow growth/late harvest & & 3.9 & 6.7 & 1.1 \\
\hline Decreased soil fertility & 1.1 & & & \\
\hline $\begin{array}{l}\text { Pest problems (on crop \& } \\
\text { in storage) }\end{array}$ & 1.7 & 3.4 & 1.1 & 1.7 \\
\hline $\begin{array}{l}\text { Low market price } \\
\text { (legumes) }\end{array}$ & & 1.1 & 5.1 & \\
\hline Market availability & & 1.1 & 2.8 & \\
\hline Livestock damage & & 6.7 & 4.8 & \\
\hline P'pea establishment & & 1.1 & 1.7 & \\
\hline$S U M$ & 22.7 & 24.7 & 32.3 & 20.3 \\
\hline
\end{tabular}

${ }^{a}$ Technologies described in table $4 .{ }^{b}$ There were 58 participating farmers in three locations, giving a total of 261 positive traits and 178 negative traits when asked to list and explain their evaluation critera.

that soil improvement would be one of the criteria mentioned. However, soil fertility was generally a minor component among farmer criteria, and women farmers in particular had limited interest in legume ability to improve soil fertility (Table 2). As has been observed in earlier work in Malawi, women farmers tend to prioritize cropping systems which produced the most food for consumption by children (Sahn et al., 1992).
Genotypes with reduced labour requirements is an important farmer objective, as illustrated by cowpea research in West Africa (Kitch et al., 1998) and bean research in East Africa (Sperling et al., 1993). These are some of the few documented examples of participatory research on legume improvement. Their results, taken together with our own experience, suggest that labour is the most important component of farmer criteria, after returns. Snapp's survey (as described 
Table 2. Criteria used by female farmers in evaluating performance of soil fertility technologies in multilocational trials in 1997 . The criteria were elicited by asking farmers to list positive and negative traits associated with each technology they had evaluated in on-farm trials

\begin{tabular}{|c|c|c|c|c|}
\hline \multirow[t]{3}{*}{ Positive traits } & \multicolumn{4}{|c|}{ Technology ${ }^{a}$} \\
\hline & $\overline{\text { Mz control }}$ & Maize/PP & Leg/PP & Maize/Tv \\
\hline & \multicolumn{4}{|c|}{ Percentage of total responses ${ }^{b}$} \\
\hline Less labour & 0.9 & & & \\
\hline Labour less/2crops & & 4.3 & 4.3 & \\
\hline Less weeds & & 4.3 & 7.1 & 2.4 \\
\hline \multicolumn{5}{|l|}{ Increased land efficiency } \\
\hline 2 crops/area & & 2.9 & 3.8 & \\
\hline Few pests & & 1.4 & 0.9 & \\
\hline Good emergence & 0.9 & & & \\
\hline Water conservation & & & & 1.3 \\
\hline Early Harvest & 6.2 & 2.9 & 4.3 & \\
\hline Good yields/food security & & 10.5 & 11.4 & 1.3 \\
\hline Fuelwood & & 2.4 & 0.9 & 2.4 \\
\hline Increased soil fertility & & 5.3 & 6.1 & 2.4 \\
\hline Pesticide & & & & 0.8 \\
\hline Increased cash sales & & 3.2 & 5.2 & \\
\hline$S U M$ & 8.3 & 37.2 & 44 & 10.6 \\
\hline \multicolumn{5}{|l|}{ Negative traits } \\
\hline Increased labour & 0.3 & 0.6 & 2 & 8.6 \\
\hline Increased weeds & 3.3 & & & \\
\hline Limited seed access & & 2.6 & 3.3 & 1.3 \\
\hline Expensive fertilizer & 2 & & & \\
\hline Low yields & 14.5 & 3.9 & 1.3 & 6.7 \\
\hline Slow growth/late harvest & & 4.6 & 6.6 & 3.3 \\
\hline Decreased soil fertility & 2.6 & & & \\
\hline $\begin{array}{l}\text { Pest problems (on crop \& } \\
\text { in storage) }\end{array}$ & 1.3 & 2 & 1.1 & 1.3 \\
\hline Low market price (legumes) & & 0.5 & 4.6 & \\
\hline Market availability & & 0.3 & 2.1 & \\
\hline Livestock damage & & 5.9 & 4.6 & 4.6 \\
\hline P'pea establishment & & 1 & 3.1 & \\
\hline$S U M$ & 24 & 21.4 & 28.7 & 25.8 \\
\hline
\end{tabular}

${ }^{a}$ Technologies described in Table $4 .{ }^{b}$ There were 41 participating farmers in three locations, giving a total of 210 positive traits and 152 negative traits when asked to list and explain their evaluation critera.

above) indicated three different categories of farmer's concern regarding labour demands of different legume systems (Tables 1 and 2). Overall, labour was about the third most often cited criteria. Men farmers also indicated significant concern about the availability and cost of inputs. Women farmers were less concerned about soil fertility returns than men, and were particularly concerned about increased labour demands in this assessment of 'best bet' legumes to improve soil fertility (Table 2). Gendered labour constraints is sup- ported by the findings of Kolli and Bantilan (1997), their research on groundnut production systems indicated that labour constraints is one of the biggest concerns of women farmers.

Soil improvement and genotype tolerance to low nutrient soils are a more variable concern among farmers, from strong interest to little or no interest. Farmer participatory research using local expert farmers to evaluate bean varieties found that tolerance to poor soils was the third most-often cited positive attribute of 
varieties chosen for home evaluation (Sperling et al.,, 1993). Kitch et al., 1998 used a very similar participatory methodology and found that farmers did not use nutrient tolerance as a selection criteria for cowpea. This may be due to species differences, as cowpea varieties generally already have a high tolerance for low nutrient soils, compared to common bean varieties that have limited tolerance for edaphic stresses (Snapp et al., 1998A; Wortmann et al., 1995). A number of researchers have suggested that only relatively well-off farmers have a strong interest in, and sufficient resources, to invest in soil ameliorating practices (Ghassali et al., 1999; Witcombe, 1999). For example, one village out of 11 in Northern Syria was found to have adequate resources and other traits - necessary but not sufficient conditions for them to rehabilitate degraded areas through seeding legumes (Ghassali et al., 1999). Only the wealthiest group of farmers in a Mali case study invested in soils through improved residue recycling (Defoer et al., 1998).

Although smallholder farmers have diverse criteria for judging genotypes and cropping systems, the point should also be made that the role of the market is increasing around the world. Kitch et al. (1998) speculate that an increasing market focus has tended to narrow farmer preferences for traits in new cowpea varieties. Farmers often capitalize on market opportunities with new varieties. Thus, a new variety may be a means to expand beyond their traditional varieties, that are already effectively addressing local nitches and tastes. This is illustrated in West Africa through a markedly uniform rating of new cowpea varieties by local expert farmers: About one-third of the selection criteria related to yield performance, one-third to quality preferences and one-third to labour-related criteria (Kitch et al., 1998). The ratings were generally constant across a wide range of locations, years and diverse socio-economic groups of farmers; the authors ascribe this uniformity to the strong market influence.

\section{Multiple farmer criteria and agromorphological traits}

Farmers often have complex criteria and are considering diverse agromorphological characteristics of varieties, and cropping systems (Fischler et al., 1996). An example of the tradeoffs farmers evaluate is presented from research conducted in partnerships with farmers in highland Central Malawi (Snapp et al., 1998A). The research evaluated the relative effectiveness of genetic tolerance and fertilizer strategies in bean systems. Soils of the region are moderately acidic $(\mathrm{pH}$ $\sim 5.3$ ) and low in soil phosphorus and nitrogen status (Snapp, 1998A). A comparison was conducted on farmer fields to evaluate yield and biological nitrogen fixation of adapted bean varieties. Locally grown varieties were compared to varieties selected for performance in low nutrient soils, results of a decade long endeavor of CIAT and national scientists from five countries. Although there was some variation in tolerance to poor soils, the largest gains in bean productivity, by far, were obtained by adding $30 \mathrm{~kg} \mathrm{P}$ fertilizer per ha (Snapp et al., 1998A). This indicates the long-term nature of genetic improvement work to improve variety tolerance to low nutrient soils. Combined use of targeted fertilizers and intercrop systems are important strategies, particularly for the near term: Genetic improvement may take many years to enhance variety tolerance to low nutrient soils.

To summarize findings regarding crop tolerance to poor soils, we constructed a matrix based on our onfarm trial data from Malawi. The matrix illustrates comparative performance in terms of potential soil benefit (estimated from crop residue nitrogen contribution) and yield under Malawi smallholder agriculture conditions (Figure 1). This indicated that legume crops vary in tolerance to low nutrient status. A general pattern emerged: Legume genotypes of short duration and determinate growth habit generally contributed minimally to soils, whereas long duration and indeterminate growth habit legumes were associated with soil benefits and tolerance to poor fertility (Figures 1 and 2A). Mucuna (Mucuna pruriens (L.) DC var. utilis) was one of the few crops which demonstrates consistent tolerance to poor soils, tremendous biomass production and high grain yields (Figure 2B). This may explain researcher observation in Benin of high farmer interest and a four-fold increase in experimentation with mucuna over 3 years (Versteeg and Koudokpon, 1993). In contrast, over the same time period, Versteeg and Koudokpon (1993) found moderate interest in a pigeonpea fallow system, and a decline of interest in hedgerow cropping systems. There are barriers to growing legumes in Malawi as well. This is indicated by the small proportion of cultivated land currently dedicated to legume production in Malawi: Less than 5\% in the Southern Lakeshore area of Malawi, and 24\% in the groundnut growing region of Central Malawi (S. Snapp, D. Rohrbach, H.A. Freeman and F. Simtowe, unpublished baseline survey, 1999). Yet, some smallholder farmers may be inter- 


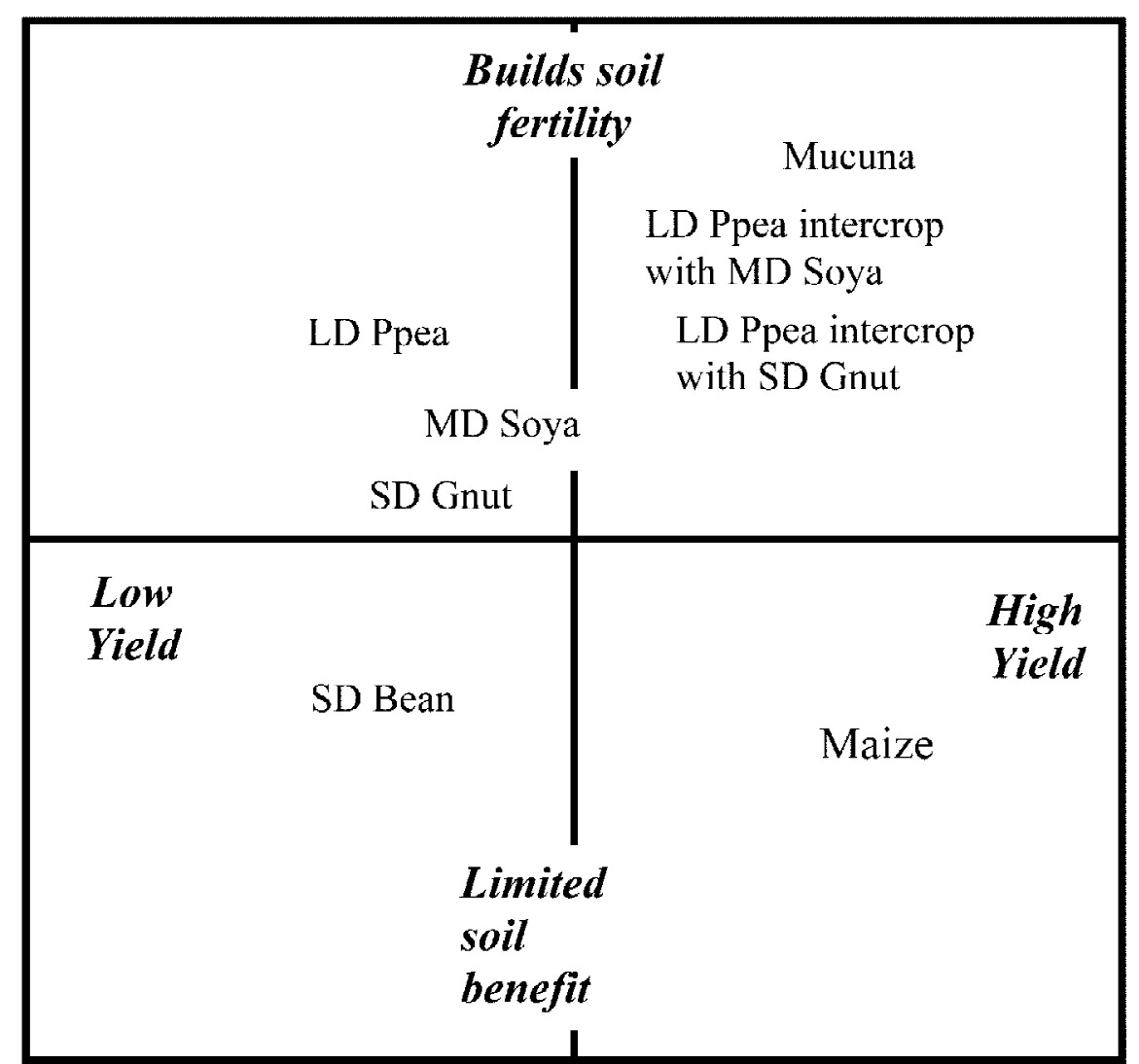

Figure 1. Schematic matrix to illustrate crop residue contribution to soil nitrogen and yield potential, from on-farm trials in Malawi. Crop varieties were categorized by growth duration. Ppea = pigeonpea, Gnut= groundnut, Soy=soyabean, bean $=$ common bean, $\mathrm{LD}=\mathrm{long}$ duration; $\mathrm{MD}=$ medium duration; $\mathrm{SD}=$ short duration.

ested in increasing legume production. The survey indicated that there was a $30 \%$ increase in experimentation with legume varieties and cropping systems over 2 years, with no increase in farmer experimentation with manures.

Contribution of crop species to improving soil is another assessment criteria, closely related to tolerance of poor soils. A clear distinction must be made between crop species that biologically fix $\mathrm{N}$, and those that do not. Cereals, such as sorghum, and cassava may be very tolerant of low soil fertility, but they do not enhance soil $\mathrm{N}$ status. In contrast, legumes have the potential to both tolerate low soil fertility and contribute to soil rehabilitation. Legumes do not all contribute to ameliorating soil fertility, as a large amount of $\mathrm{N}$ is removed in grain and fodder. Recycling residues and growing legumes with high quality residues are crucial to deriving soil fertility benefits from legume intensification (Defoer et al., 1998).
Legumes with a indeterminate growth habit may be the best bet for smallholder farmers interested in ameliorating soils. Indeterminancy is related to high pest tolerance, consistent growth on low nutrient soils, and production of high quality residues. Indeterminacy improves pest resistance through a compensatory ability to regrow and thus mitigate pest damage. The soil benefits of indeterminate legumes include high nitrogen fixation rates, due to the ability to exploit favorable growth periods over a long growing season, and a protective soil cover from leaf biomass and senescent material. Our findings from on-farm trials in Malawi are similar to studies in Benin (Versteeg and Koudokpon, 1993): Aboveground, leafy biomass production levels of mucuna from 2 to $10 \mathrm{t} / \mathrm{ha}$, and pigeonpea from 1 to $4.5 \mathrm{t} / \mathrm{ha}$ (and see Figure 2A).

Indeterminate legumes are thus recommended for ameliorating soils in low fertility, environmentally stressed conditions. However, indeterminacy is associated with two negative traits that must be considered. 

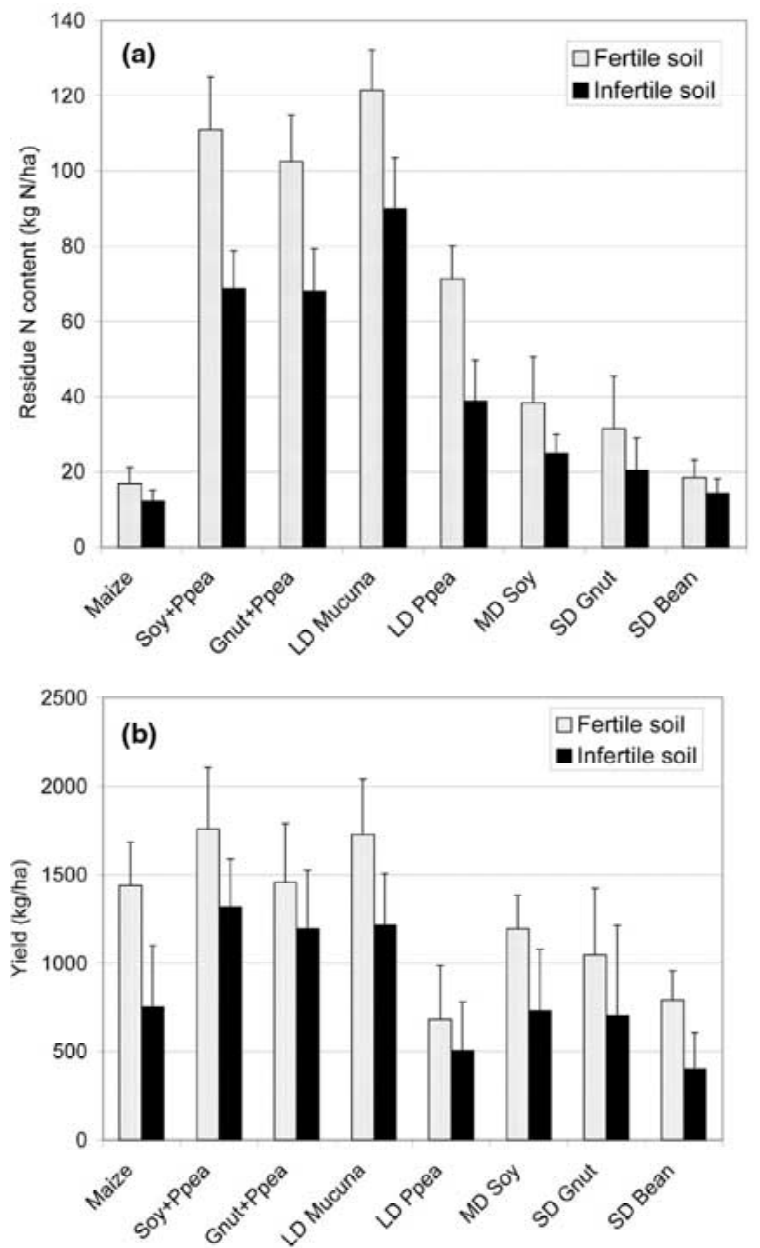

Figure 2. (A) Data from first year of a rotation and intercrop system comparison in Malawi, averaged across 1997-98 and 1998-99 growing seasons. Average and standard deviation (bars) are reported for residue nitrogen from trials conducted at high fertility sites (organic carbon above $1.4 \%$ ) and low fertility sites (organic carbon below 1.4\%). Trials carried out with 46 farmers, with the exception of groundnut (26 farmers) and soyabean (20 farmers). Above-ground crop residue dry weight biomass measurements were conducted at approximately 3 weeks before grain harvest. A sub-sample of residues were ground and analyzed to determine nitrogen percentage by acid digestion and nitrogen determination, to calculate total nitrogen content of residues. Trial design and preliminary results described in Kanyama-Phiri et al. (2000). Abbreviations were as in Figure 1. (B) Data from first year of a rotation and intercrop system comparison in Malawi, averaged across 1997-98 and 1998-99 growing seasons (see Figure 2A). Grain yield performance is reported as an average and standard deviation (bars) for high fertility sites (organic carbon above 1.4\%) and low fertility sites (organic carbon below $1.4 \%$ ). Trial description and preliminary results described in Kanyama-Phiri et al. (2000). Abbreviations were as in Figure 1.

That is: High labour demand at harvesting and a long period to wait before food is produced. An example is cowpea, where a higher labour demand is associated with a long duration, spreading growth habit (Kitch et al., 1998). It is interesting that farmers are interested in selecting for both types of cowpea, bush and spreading: These fit different niches (Kitch et al., 1998). Farmer ranking of groundnut traits suggests that bunch types are seen as less labour intensive for harvest compared to spreading types, and often are early producers (D. Boughton, pers. comm., 1997). Of particular concern for the unimodal semi-arid tropics, early maturing groundnut varieties can provide urgently needed food during the 'hungry time' before cereal harvest. In terms of tolerance to infertile soils, groundnut is somewhat unpredictable (Figure 2B). Some large seed types are associated with long duration genotypes that have limited seed fill characteristics, and poor yields under drought-stress or poor soil fertility, whereas other long-duration groundnuts are tolerant of low nutrients (Syamasonta, 1990). Providing a range of plant growth types-tailored to different marketing and household niches-may be an under-exploited approach for breeders to consider.

A wide range of pigeonpea varieties are grown in S.E. Africa, ranging from determinate to indeterminate types, and extra short duration to long duration types ratooned and grown over 2 years (ICRISAT, 1998). The potential of pigeonpea could be exploited further through developing varieties that maximize different features, such as: Intercropping performance (canopy architecture), extended soil cover over a long period, providing a bonus grain or vegetable crop, fuel wood and high quality residues. As pigeonpea is known to fix high amounts of nitrogen and has the ability to solubilize phosphorus from unavailable forms (Ae et al., 1990), emphasis should be given to selecting pigeonpea cultivars with high nutrient residues. Such improved pigeonpea could be used as a biological technology to improve soil fertility. Pigeonpea is one of the few crops with potential to enhance soils with minimal labour inputs and low seed costs, compared to other green manure and agroforestry species (Snapp et al., 1998B).

\section{Designing intensified systems}

Multiple evaluation criteria include short-term issues of food security, income generation and labour demands, and long-term issues of soil fertility regeneration and resource conservation. Designing improved varieties is one approach, where ideally low nutrient tolerant varieties can be bred which have minimal 
Table 3. Pigeonpea and maize yields from on-farm trials at six sites in Semi-arid Eastern Kenya (ICRISAT, 1998). Standard error for pigeonpea yield: variety is 0.023 , for agronomy (paired row versus single row) is 0.024 , and variety by agronomy is 0.041 . Standard error for maize yield: variety is 0.084 , for agronomy is 0.078 , and variety by agronomy is 0.118 .

\begin{tabular}{lccc}
\hline Agronomy & $\begin{array}{c}\text { Improved } \\
\text { Variety }\end{array}$ & Farmer Variety & Mean \\
& \multicolumn{2}{c}{ Pigeonpea Yield (t/ha) } \\
Improved: Paired Row & 1.46 & 1.50 & 1.48 \\
Farmer: Single Row & 0.81 & 1.09 & 0.95 \\
& \multicolumn{4}{c}{ Maize (t/ha) } \\
Improved: Paired Row & 1.25 & 1.54 & 1.41 \\
Farmer: Single Row & 1.23 & 1.46 & 1.35 \\
\hline
\end{tabular}

labour demands and contribute large amounts of biological fixed nitrogen through high quality residues. However, one variety cannot meet all demands, and combining genotypes in purposively designed intercropping systems is another approach (Willey et al., 1997).

Participatory on-farm research in Kenya has evaluated pigeonpea varieties (farmer and improved) grown in different intercrop systems with maize (ICRISAT, 1998). The commonly grown 'farmer pigeonpea intercropping system' involves one pigeonpea row per three rows of maize. This single row system was evaluated in comparison to a paired pigeonpea row (two rows grown close together, as one row) intercropped with three rows of maize. Results are promising as the paired row system had 59\% higher pigeonpea yields than the single row system (Table 3). The intercrop systems were designed to incorporate pigeonpea as a bonus crop; where maize was the dominant food crop. Overall, this goal was met as the pigeonpea intercrop systems did not reduce maize yields, compared to sole crop maize. However, the improved pigeonpea variety, Kat81/3/3, was a spreading or 'bushy' type and it was not a good intercrop partner, with multiple branches shading maize and causing occasional yield reductions. In contrast, the farmer variety of pigeonpea was an excellent intercrop partner, not reducing maize yields (Table 3).

Researchers in Kenya have recently reviewed pigeonpea breeding program objectives, to incorporate a wider range of criteria, including: High yielding, and erect or semi-erect growth type with minimal 'bushy' characteristics (ICRISAT, 1998). Although there is a ways to go in selecting intercrop-adapted varieties some progress has been achieved. Pigeonpea varieties ICEAPs 00020,00040,00053 are now being evaluated in five countries, and have received a very favourable response from end users (Figure 2). The criteria used by farmers to evaluate long duration pigeonpea include 'intercropping ability', which was not present in improved variety 00053 , the least favoured by farmers of the new pigeonpea varieties.

In Malawi, the dominant system is sole crop maize, and researchers are working with farmers to experiment with different systems that intensify the use of long duration, indeterminate legumes. Starting in 1996, an interdisciplinary group evaluated legume intensified cropping systems in over 100 on-farm trials using a satellite trial design where researcher evaluation of system performance is cross-checked with farmer evaluation (Kanyama-Phiri et al., 2000; Snapp, 1999). Promising intercrops combined long duration pigeonpea (LDP) with maize, and with a short duration groundnut variety (SDG), or with soyabean (Table 4).

The design of the SDG/LDP system was developed to combine SDG high yield potential and low labour demand (compared to spreading type groundnut varieties) with LDP soil coverage and biological nitrogen fixation. The SD groundnut met farmer criteria for early harvest, increased food security and exploitation of a market niche. The upright, bunch growth type of the short duration groundnut also requires less labour to harvest, as concentrated pods require less soil to be dug. However, the soil fertility contribution of SD groundnut can be limited (Figure 2A). Yields can also be erratic under nutrient deficient conditions, note high standard deviation (Figure 2B). Slow, early growth aboveground by long duration pigeonpea minimized competition with the short duration groundnut, and contributed a 'bonus' grain crop, as well as substantial soil fertility benefits (Figure 2A, B). Presumably, the intercropped pigeonpea fixed more nitrogen (due to a longer growth period), exploited nutrients below the more limited groundnut root system, and recycled nutrients which would have been lost after the SD groundnut harvest.

Results from this farmer participatory research indicated that doubling up SD groundnut and LD pigeonpea had consistently high land area equivalent ratios and calorie production was $28 \%$ higher than sole cropped, unfertilized maize (Kanyama-Phiri et al., 2000; Figure 2B). The MD soyabean/LD pigeonpea intercrop was successful at producing grain combined 


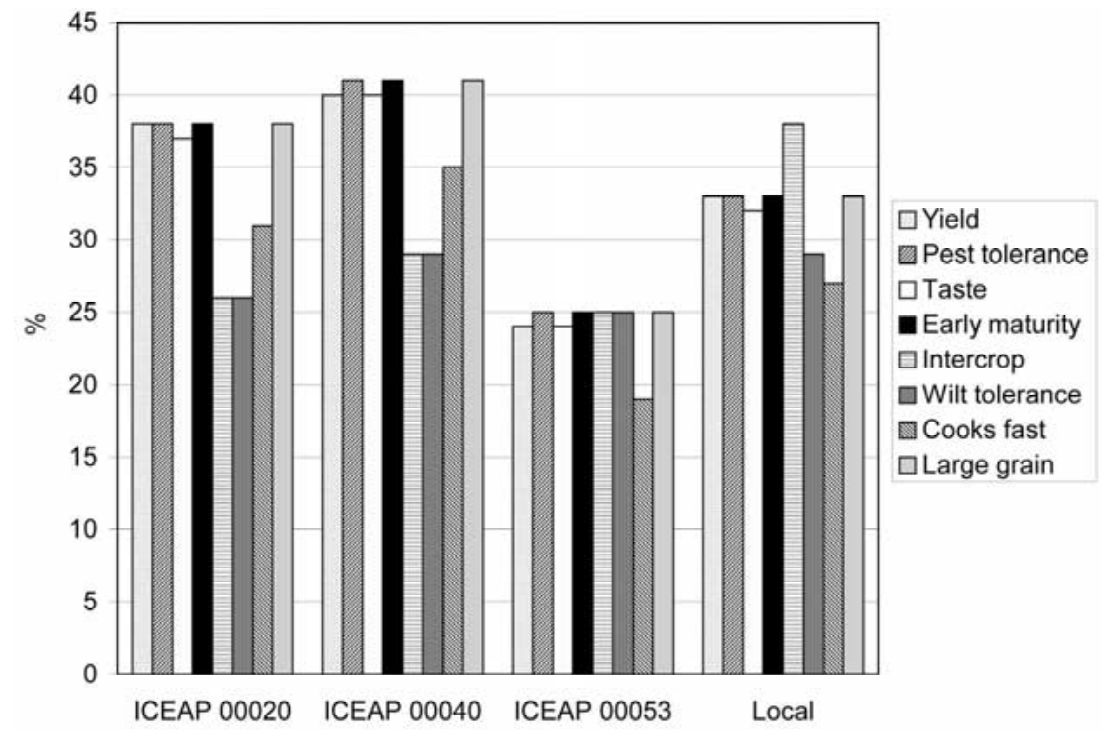

Figure 3. Results of preference rating exercise conducted with farmers in Kenya evaluating 5 pigeonpea varieties to identify desirable traits and compare improved and local pigeonpea varieties (African Development Bank Report No. 12, 1999).

with soil benefits as well (Figure 2A, B). Rating exercises conducted with farmers who had participated in the research demonstrated marked interest in the two pigeonpea intensified systems (Table 5). Women farmers in particular preferred 'doubling up legume systems' to their current cropping systems. The labourefficiency of weeding doubled up legume systems was ranked high by farmers (Table 5). Farmer selection criteria highlighted problems as well, primarily due to concerns about high cost and unavailability of legume seeds (Tables 1 and 2). These legume systems are in a research, development and dissemination process with a focus on flexibility: they are potentially best bets among a basket of options for smallholder farmers. The emphasis is on a range of options which farmers can adapt to their needs, in contrast to blanket recommendations or bundled systems (Ahmed et al., 1997). Flexibility and options are particularly important for farmer adoption of soil improving technologies (Okali et al., 1994).

The question remains, what are the long-term environmental consequences of widespread adoption of low-nutrient adapted varieties and cropping systems? Questions have been raised about the sustainability of crop varieties that effectively exploit nutrients in a low-nutrient environment. Preliminary results from on-farm measurements of nutrient input and outputs in the intercrop systems indicate a complex picture: Intercropping maize with $\mathrm{LD}$ pigeonpea can enhance soil coverage, reduce erosion and significantly im- prove the phosphorus balance, compared to maize monoculture systems with little or no fertilizer inputs (Snapp, 1998B). It is possible that the ability of long duration, indeterminate pigeonpea varieties to solubilize phosphorus (effectively mining the soil for $\mathrm{P}$ ), may be balanced by the enhanced soil cover and reduced erosion also associated with a pigeonpea intercrop system. The potential to biologically enhance availability of soil $\mathrm{P}$ is often related to ability to reduce losses, and thus increase retention of nutrients in plant-available forms (Snapp, 1998B).

\section{Conclusions}

The major challenge researchers face in designing cultivars and cropping systems that meet farmer preferences is that high performance is demanded, yet low labour inputs and edaphic stresses are the norm under smallholder environments. Given this, farmers require a wide range of crop types and systems to meet diverse demands.

Researchers should focus on identifying opportunities and designing a range of best bet options. This includes varieties that have low labour demands, as well as high yield potential in nutrient-poor soils. A range of short duration varieties, to meet needs for food and market opportunities early in the growing season, should be complemented with long-duration varieties that perform very well under edaphic stress 
Table 4. Soil fertility improving, best bet legume intensification technologies, description in terms of biological and farmer considerations

\begin{tabular}{|c|c|c|c|}
\hline Technology & $\begin{array}{l}\text { Population } \\
\text { density } \\
(\times 1000)\end{array}$ & Biological characteristics & $\begin{array}{l}\text { Farmer perceptions of } \\
\text { characteristics }\end{array}$ \\
\hline 1. Maize control & Maize: 37 & $\begin{array}{l}\text { Maize hybrid MH18, three maize plants } \\
\text { per planting stations, } \\
0.9 \mathrm{~m} \times 0.9 \mathrm{~m} \text {. }\end{array}$ & $\begin{array}{l}\text { Current farmer } \\
\text { practice throughout } \\
\text { Malawi, productive } \\
\text { with minimal labour }\end{array}$ \\
\hline $\begin{array}{l}\text { 2. Maize }+ \\
\text { pigeonpea }(\mathrm{PP}) \\
\text { intercrop }\end{array}$ & $\begin{array}{l}\text { Maize: } 37 \\
\text { PP: } 37\end{array}$ & $\begin{array}{l}\text { Temporal compatibility. PP variety ICP } \\
9145 \text { planted at the same time as maize, } \\
3 \text { plants per planting station spaced } \\
\text { halfway between each maize station. PP } \\
\text { grows slowly, which reduces } \\
\text { competition with maize. }\end{array}$ & $\begin{array}{l}\text { PP is a bonus crop, } \\
\text { low density system } \\
\text { minimizes impact on } \\
\text { maize yields. }\end{array}$ \\
\hline $\begin{array}{l}3 . \text { Legume + } \\
\text { PP intercrop } \\
\text { year } 1, \\
\text { rotation with } \\
\text { maize year } 2 \\
\text { (Legume }= \\
\text { groundnut or } \\
\text { soyabean) }\end{array}$ & $\begin{array}{c}\text { Or } \\
\text { Soyabean: } \\
222 \\
\text { PP: } 37\end{array}$ & $\begin{array}{l}\text { Groundnut variety JL } 24 \text { or CG } 7 \text { was } \\
\text { grown as a single row } 7 \mathrm{~cm} \text { spacing on } \\
\text { ridges spaced at } 0.9 \mathrm{~m} \text { spacing. To } \\
\text { enhance residue biomass quantity and } \\
\text { quality, Ppea is intercropped with the } \\
\text { shortduration grain legume. Soyabean = } \\
\text { double row of } 10 \mathrm{~cm} \text { spaced planted } \\
\text { along each ridge. Indeterminate variety } \\
\text { Magoye that does not require inoculum } \\
\text { (nodulates with indigenous Rhizobium). }\end{array}$ & $\begin{array}{l}\text { Legume seed density } \\
\text { takes into account } \\
\text { expense of g'nut seed } \\
\text { and farmer-adoptable } \\
\text { seeding rates. Ppea is } \\
\text { a bonus crop. } \\
\text { Higher density of } \\
\text { soyabean is possible } \\
\text { than groundnut, give } \\
\text { the cost of the seed. }\end{array}$ \\
\hline $\begin{array}{l}\text { Maize }+ \\
\text { tephrosia relay } \\
\text { intercrop }\end{array}$ & $\begin{array}{l}\text { Tephrosia: } \\
20 \mathrm{~kg} / \mathrm{ha} \\
\text { Maize: } 37\end{array}$ & $\begin{array}{l}\text { Temporal compatibility, enhanced by } \\
\text { planting tephrosia at } 1 \text { st weeding. } \\
\text { Tephrosia has an initially slow growth } \\
\text { habit. Green manure screening studies } \\
\text { have shown the widespread adaptability } \\
\text { of Tephrosia to Malawi agroecosystems, } \\
\text { producing about } 2 \text { t/ha as a relay } \\
\text { intercrop. }\end{array}$ & $\begin{array}{l}\text { For a green manure } \\
\text { system to be adopted } \\
\text { by farmers, it must } \\
\text { minimize labour } \\
\text { required. Seed is } \\
\text { broadcast along ridge } \\
\text { and incorporated by } \\
\text { weeding operation. }\end{array}$ \\
\hline
\end{tabular}

and provide secondary benefits such as enhanced soil fertility through high-quality residues, and weed suppression. Presenting farmers with the combination of short and long-duration varieties in intercrop systems should also be considered, and genetic improvement efforts need to take into account breeding for superior intercrop performance. Opportunities may exist to take advantage of occasionally extended growing opportunities, with bonus 'extra yield' potential from intercrops, combined with more consistent soil protection.

\section{Acknowledgements}

The Rockefeller Foundation is gratefully acknowledged for funding and all manner of support for the research carried out in Malawi. The authors are indebted to the many farmers, extension workers and research colleagues in Southern and Eastern Africa who have made possible this research on legume intensification cropping systems and management options for low nutrient soils. 
Table 5. Farmer rating of technology traits across all sites, where scale used for rating was Very low $=1$, Low $=2$, High $=3$, Very high=4. Technologies were rated independently. Data from five Malawi case study sites with a total of 110 participating farmers, S. Snapp, 1999. Technologies described in Table 4

\begin{tabular}{lccccc}
\hline Location & $\begin{array}{c}\text { Weeding \& } \\
\text { other labour } \\
\text { Requirements }\end{array}$ & $\begin{array}{c}\text { Seed } \\
\text { availability }\end{array}$ & $\begin{array}{c}\text { Contribution } \\
\text { to food } \\
\text { security }\end{array}$ & $\begin{array}{c}\text { Contribution } \\
\text { to cash } \\
\text { sales }\end{array}$ & $\begin{array}{c}\text { Contribution } \\
\text { to soil } \\
\text { fertility }\end{array}$ \\
\hline Technology & & & & & \\
$\mathrm{Mz}$ & 3.1 & 3.3 & 2.2 & 2.3 & 1.5 \\
$\mathrm{MzPP}$ & 2.5 & 1.9 & 3.4 & 2.9 & 3.1 \\
$\mathrm{GPP}^{a}$ & 2.2 & 1.7 & 3.3 & 3.4 & 3.1 \\
$\mathrm{MzT}_{\mathrm{LSD}}$ & 2.8 & 1.3 & 2.0 & 1.9 & 1.8 \\
\hline
\end{tabular}

${ }^{a} \mathrm{GPP}=$ groundnut/pigeonpea rotation technology for all locations except Bembeke where soyabean was the shortduration grain legume substituted for groundnut, due to the high altitude.

\section{References}

Ae N, Arihara J, Okada K, Yoshihara T and Johansen C 1990 Phosphorus uptake by pigeon pea and its role in cropping systems of the Indian subcontinent. Science 248, 477-480.

African Development Bank 1999 Improvement pigeon pea in Eastern and Southern Africa: project completion report No. 12, ICRISAT, Nairobi, Kenya.

Ahmed M M, Rohrbach D D, Gono L T, Mazhangara E P, Mugwira L, Masendeke D D and S Alibaba 1997 Soil fertility management in communal areas of Zimbabwe: Current practices, constraints and opportunities for change. Results of a diagnostic survey. Southern Eastern Africa Region Working Paper No. 6. International Crops Research Institute for the Semi-Arid Tropics (ICRISAT), Bulawayo, Zimbabwe.

CARE International 1998 Malawi Participatory Livelihood Assessment Exercise (Synthesis Report). CARE, Lilongwe, Malawi, mimeo. $75 \mathrm{pp}$.

Chambers R and Ghildyal B P 1985 Agricultural research for resource-poor farmers: The farmer-first-and-last model. Agricul. Admin. 20, 1-30.

Defoer T, De Groote H, Hilhorst T, Kante S and Budelman 1998 Participatory action research and quantitative analysis for nutrient management in southern Mali: A fruitful marriage. Agric. Ecosyst. Environ. 71, 215-228.

Ferguson A 1994 Gendered science: a critique of agricultural development. Am. Anthro. 96, 540-552.

Fischler M, David S, Farley C, Ugen M and Wortmann C 1996 Applying farmer participatory research methods to planning agricultural research: Experiences from Eastern Africa. J. Farm. Syst. Research-Extension 6, 37-54.

Ghassali F, Cocks P S, Osman A E, Gintzburger G, Christiansen S, Semaan A and Leybourne M 1999 Rehabilitation of degraded grasslands in North Syria: Use of farmer participatory research to encourage the sowing of annual pasture legumes. Expl. Agric. 35, 489-506.

Heong K L and Escalada M M 1999 Quantifying rice farmers' pest management decisions: Beliefs and subjective norms in stem borer control. Crop Protect. 18, 315-322.

ICRISAT 1998 Improvement of pigeonpea in Eastern and Southern Africa: Project completion report, December, 1998. P.O. Box39063, Nairobi, Kenya.
Katayama K, Ito O, Matsunaga R, Adu-Gyamfi J J, Rao T P, Anders M M and Lee K K 1995 Nitrogen balance and root behavior in four pigeonpea-based intercropping systems. Fertil. Res. 42, 315-319.

Kanyama-Phiri G Y, Snapp S S, Kamanga B and Wellard K 2000 Towards Integrated Soil Fertility Management in Malawi: Incorporating participatory approaches in agricultural research. Managing Africa's Soils No. 11. IIED, UK. 27 pp.

Kitch L W, Boukar O, Endondo C and Murdock L L 1998 Farmer acceptability criteria in breeding cowpea. Expl. Agric. 34, 475486.

Kolli D R and Bantilan M C S 1997 Gender-related impacts of improved agricultural technologies: Identification of indicators from a case study. Gender, Techn. Devel. 1, 372-393.

Okali C, Sumberg J E and Reddy K C 1994 Unpacking a technical package: Flexible messages for dynamic situations. Expl. Agric. 30, 299-310.

Sahn D E, Van Frausum Y and Shively G 1992 The adverse nutrition effects of taxing export crops in Malawi. Cornell Food and Nutrition Policy Program, Working paper No. 29. Washington, D.C., USA 31 pp.

Snapp S S 1998A Soil nutrient status of smallholder farms in Malawi. Comm. Soil Sci. Plant Anal., 29, 2571-2588.

Snapp S S 1998B Phosphorus and sustainability of sub-Saharan Africa smallholder farms. In Phosphorus in Plant Biology: Regulatory Roles in Molecular, Cellular, Organismic and Ecosystem Processes. Eds. JP Lynch and J Deikman. pp. 59-72. American Society of Plant Physiologists, Madison, Wisconsin, USA.

Snapp S S, Aggarwal V D and Chirwa R M 1998A Note on phosphorus and genotype enhancement of biological nitrogen fixation and productivity of maize/bean intercrops in Malawi. Field Crops Res. 58, 205-212.

Snapp S S, Mafongoya P L and Waddington S 1998B Organic matter technologies to improve nutrient cycling in smallholder cropping systems of Southern Africa. Agric., Eco. Envir. 71, 187-202.

Snapp S S 1999 Mother and baby trials: A novel trial design being tried out in Malawi. Target Newsletter 17, 8.

Sperling L, Loevinsohn M E and Ntabomvura B 1993 Rethinking the farmer's role in plant breeding: Local bean experts and onstation selection in Rwanda. Expl. Agric. 29, 509-519.

Syamasonta M B 1990 A review of 'pops' research in Zambia. In Proceedings of the fourth regional groundnut workshop for 
Southern Africa, 19-23 March, 1990, Arusha, Tanzania. pp. 17-21, ICRISAT.

Versteeg M N and Koudokpon V 1993 Participative farmer testing of four low external input technologies, to address soil fertility decline in Mono Province (Benin). Agric. Systems 42, 265-276.

Willey R W, Mohammed N and Morse S 1997 Factors affecting compensation in intercropping when one component fails. Trop. Agric. 74, 313-316.
Witcombe J R 1999 Do farmer-participatory methods apply more to high potential areas than to marginal ones. Outlook Agric. 28, 43-49.

Wortmann C S, Lunze L, Ochwoh V A and Lynch L 1995 Bean improvement for low fertility soils in Africa. African Crop Sci. J. 3, 469-477. 